Original Research Paper

\title{
Baseline Concentrations of 11 Elements as a Function of Land uses in Surface Soils of the Katangese Copperbelt Area (D.R. Congo)
}

\author{
${ }^{1,2}$ Martin T. Mpinda, ${ }^{1}$ Tresor N. Kisimba, ${ }^{3}$ Theodore M. Mwamba, \\ ${ }^{3}$ Emery L.M. Kasongo, ${ }^{4}$ Arthur T. Kaniki and ${ }^{1}$ Basile B. Mujinya \\ ${ }^{1}$ Biogeochemistry and Ecology of Tropical Soils and Ecosystems (BESET), Faculty of Agricultural Sciences, \\ University of Lubumbashi, Lubumbashi B.P: 1825, DR. Congo \\ ${ }^{2}$ Département des Sciences de l'Environnement (DES) Faculté des Sciences des Aliments et de l'Environnement (FSAE), \\ Université Nouveaux Horizons, Lubumbashi, Haut-Katanga, DR. Congo \\ ${ }^{3}$ Department of Renewable Natural Resources Management, Faculty of Agricultural Sciences, \\ University of Lubumbashi, Lubumbashi B.P: 1825, DR. Congo \\ ${ }^{4}$ Department of Chemical Engineering, University of Lubumbashi, Lubumbashi, Democratic Republic of the Congo
}

\section{Article history}

Received: 22-09-2021

Revised: 29-11-2021

Accepted: 08-12-2021

Corresponding Author:

Martin T. Mpinda

Biogeochemistry and Ecology

of Tropical Soils and

Ecosystems (BESET), Faculty

of Agricultural Sciences,

University of Lubumbashi,

Lubumbashi B.P: 1825, DR.

Congo

Email: mtmartin925@gmail.com
Abstract: The Katangese Copperbelt Area (KCA) located south-eastern of D.R. Congo presents high concentration of Metal Trace Elements (MTE) due to a rich natural geochemical background and intense mining activities. However, the lack of data on specific baseline concentrations makes it difficult to assess and monitor the environmental quality of soils in the region. In this study, 11 MTE were measured across three land uses (croplands, forest and mining areas) to assess their baseline concentrations in topsoils of the KCA. Results showed the following (geometric) mean concentrations (mg. $\left.\mathrm{kg}^{-1}\right)$ in cropland soils: $\mathrm{Al}$ (54.6), $\mathrm{Co}(0.5), \mathrm{Cr}(0.1), \mathrm{Cu}$ (3.7), Fe (33.0), Mn (44.8), Ni (0.2), Pb (0.6), Zn (1.0), Ti (2.4), pH (5.3); in forests: $\mathrm{Al}$ (148.0), $\mathrm{Cd}(0.1), \mathrm{Co}$ (1.9), $\mathrm{Cr}$ (2.2), $\mathrm{Cu}$ (12.3), $\mathrm{Fe}$ (156.4), $\mathrm{Mn}$ (86.9), $\mathrm{Ni}$ (1.1), $\mathrm{Pb}$ (1.9), $\mathrm{Zn}$ (3.7), $\mathrm{Ti}$ (0.4), $\mathrm{pH}$ (4.3); and in mining areas: $\mathrm{Al}$ (42.8), Cd (1.3), $\mathrm{Co}$ (7.0), $\mathrm{Cr}$ (0.1), Cu (115.5), $\mathrm{Fe}$ (53.3), $\mathrm{Mn}$ (26.1), Ni (0.5), Pb (8.2), Zn (93.1), $\mathrm{Ti}(0.3), \mathrm{pH}$ (5.8). $\mathrm{Cu}$ and $\mathrm{Zn}$ were higher in mining areas compared to other land uses, demonstrating a prevalent influence of mining activities in altering the natural background of metals concentrations in the region. By contrast, croplands and forest shared a similar trend of $\mathrm{Al}$ and $\mathrm{Mn}$ contents, suggesting a mild influence of agricultural activity. This study is the first attempt to establish reference values of MTE contents in the KCA soils and thus provides valuable information for legislative purposes and for soil quality assessment.

Keywords: Environemental Pollution, Contamination, Metal Concentration, Trace Elements

\section{Introduction}

Ecosystem pollution with metals is of great concern due to the inherent adverse effects on living organisms including humans (Herselman, 2007). In the prospect to preventing humans' exposure, assessing the environmental quality of soils represents a crucial step, for which understanding the patterns of trace elements concentrations is of critical importance (Albright, 1998).

The behaviour of metals in soils is constrained by various geochemical processes and $\mathrm{pH}$ is one of the most important factors determining the forms of metal occurrence and influencing metal solubility and speciation and thus toxicity
(Temminghoff et al., 1998). The first approach for soil contamination evaluation is the determination of the total available trace element content (Ballesta et al., 2010). In this regard, the natural background concentrations of trace elements are suggested as a reference to identify polluted soils and eventually to propose a plan for their proper management (Herselman, 2007; Ballesta et al., 2010).

Referred to as the natural range of concentration prior to any anthropogenic influence, the concept of geochemical background concentrations is scarcely considered however, and related data are quasi-inexistant for most environments. Conventionally, $95 \%$ of the expected range of background 
concentrations is designated as baseline concentrations, which is most often considered as reference to evaluate soil contamination levels (Herselman, 2007).

Several sources affecting the natural background concentrations of metals in soils are listed including mining, agricultural and other industrial activities (Baize and Sterckeman, 2001; Zhao et al., 2007). In the The Katangese Copperbelt Area (KCA), located south-eastern of the Democratic Republic of Congo, significant deposits of Copper $(\mathrm{Cu})$, Cobalt $(\mathrm{Co})$ and other metals are found (Leteinturier and Malaisse, 1999). Hence, most environmental studies have revealed widespread soil pollution in the region (Banza et al.,2009; Lubalega et al., 2015; Katemo et al., 2010; Mpundu et al. 2013). In most cases, these studies expressed the metal contents in soil referring to the so-called universal concentrations of trace elements. A reference study by Ngoy et al. (2018) provided an interesting overview of metal contents in the region, but did not present the related baseline concentration. Moreover, none of these studies established the lower and upper limits of elements contents based on the baseline calculation that can be used as soil quality reference values for the KCA. This makes it difficult to adequately establish quality standards to detect and monitor sites affected by metals contamination in the region. Yet the concentrations of trace elements in soils depends on the mineralogical composition of the parent material and is influenced by weathering processes; therefore, it appears inappropriate to use universal reference concentrations (Ballesta et al., 2010; Tack et al., 1997). Alternatively, a more appropriate approach would imply establishing baseline concentrations on a regional basis to be used as a reference in the identification of contaminated soils (Herselman, 2007). Unfortunately, no data on baseline concentrations of trace elements exist for the Katangese Copperbelt Area (KCA).

The present study was initiated to (i) establish baseline concentrations of 11 potentially toxic trace elements (i.e., $\mathrm{Mn}, \mathrm{Zn}, \mathrm{Cu}, \mathrm{Co}, \mathrm{Cr}, \mathrm{Pb}, \mathrm{Cd}, \mathrm{Ti}, \mathrm{Ni}, \mathrm{Al}, \mathrm{Fe}$ ) in soils of the Katangese Copperbelt Area (KCA); and (ii) investigate their variation under 3 different land uses (croplands, forest and mining areas). We collected topsoils (0-20) across different land uses and measured element content using the Inductively coupled plasma - optical emission spectrometry. The results of this research can be used as soil quality reference values in assessing anthropogenic vs. natural levels of trace elements in the KCA.

\section{Materials and Methods}

\section{Study Area}

This study was conducted in the KCA extending from Sakania to Kolwezi (Haut-Katanga and Lualaba provinces, D.R. Congo) (Fig. 1). Climate of the KCA is humid subtropical (Köppen climate classification Cwa) with one dry season (May to September) and one wet season (November to April). Annual mean rainfall is about $1300 \mathrm{~mm}$, the majority falling during the wet season. The temperature fluctuates from $15-17^{\circ} \mathrm{C}$ (early dry season) to $31-33^{\circ} \mathrm{C}$ (late dry season), with the mean annual temperature averaging $20^{\circ} \mathrm{C}$ (Leblanc and Malaisse, 1978; Saad et al., 2012). The bedrock of the KCA consists of $\sim 10,000 \mathrm{~m}$ thick sedimentary succession that belongs to Neoproterozoic Katangan Supergroup (Kampunzu et al., 2000; Kampunzu et al., 2009). Based on the regional occurrence of two diamictites (the 'Grand Conglomérat' and 'Petit Conglomérat'), the Katangan sedimentary succession is subdivided in three lithostratigraphic groups i.e., from base to top, the Roan, Nguba and Kundelungu Groups (Cailteux et al., 2005; Mujinya et al., 2014). The Roan Group comprises siliciclastic and dolomitic rocks, whereas the Nguba and Kundelungu Groups largely consist of siliciclastic rocks, with one major carbonate unit occurring as part of the Nguba Group (Kakontwe Limestone) (Batumike et al., 2007; Mujinya et al., 2014). The primary vegetation of the region is miombo woodland (Malaisse, 1974). Strong anthropogenic degradation of the vegetation resulted in woodland being substituted by a secondary grass savannah in the peri-urban zones of the KCA (Malaisse, 1973).

\section{Sample Collection and Laboratory Analyses}

Surface soils $(0-20 \mathrm{~cm})$ used in this study were collected in Lubumbashi and its surroundings between 2015 and 2021. The sampling area covers 3 land uses with a total of 490 samples (Fig. 1): Agricultural land (450 samples), mining sites (24 samples) and miombo woodland (16 samples).

Analyses were performed on air-dried soil fractions $(<2 \mathrm{~mm})$. The soil $\mathrm{pH}$ was measured potentiometrically in a 1:2.5 (W/V) suspension of $1 \mathrm{M} \mathrm{KCl}$. Total trace element contents were measured using the Inductively Coupled Plasma-Optical Emission Spectrometry (ICP-OES: Optima 8300 078S1509233; detection limits: $0.5-10$ ppm). Briefly, the trace elements analyzed in the soil samples were: $\mathrm{Mn}, \mathrm{Zn}, \mathrm{Cu}, \mathrm{Co}, \mathrm{Cr}, \mathrm{Pb}, \mathrm{Cd}, \mathrm{Ti}, \mathrm{Ni}, \mathrm{Al}$ and $\mathrm{Fe}$. Digestion of the sample was performed by wet extraction with EDTA at $\mathrm{pH} 4.65$ following the protocol described in the soil analysis manual (Van Ranst et al., 1999). All analyses were performed in triplicate. Initially, a wider set of trace elements was considered, of which 11 were retained based on their threshold for detection by the spectrometer used for elements quantification.

\section{Data Processing and Statistics}

Principal Component Analysis (PCA) was performed using the package Facto Miner in R software (4.0.1) to characterize studied land uses based on measured elements (Team, 2013). The Arithmetic Mean (AM), Arithmetic Standard Deviation (ASD), Geometric Mean 
(GM), Geometric Standard Deviation (GSD), minimum, maximum and median were calculated to compare trace element contents and the $\mathrm{pH}$ across land uses. The AM and ASD are best estimates of geochemical abundance of an element, whereas the GM and GSD are better maximum likelihood estimators for most geochemical data. Baseline concentrations of the 11 trace elements were calculated using $\mathrm{GM} / \mathrm{GSD}^{2}$ and $\mathrm{GM} \times \mathrm{GSD}^{2}$ of the samples, respectively as the lower and the upper limit of the established baseline (Dudka and Markert, 1992).

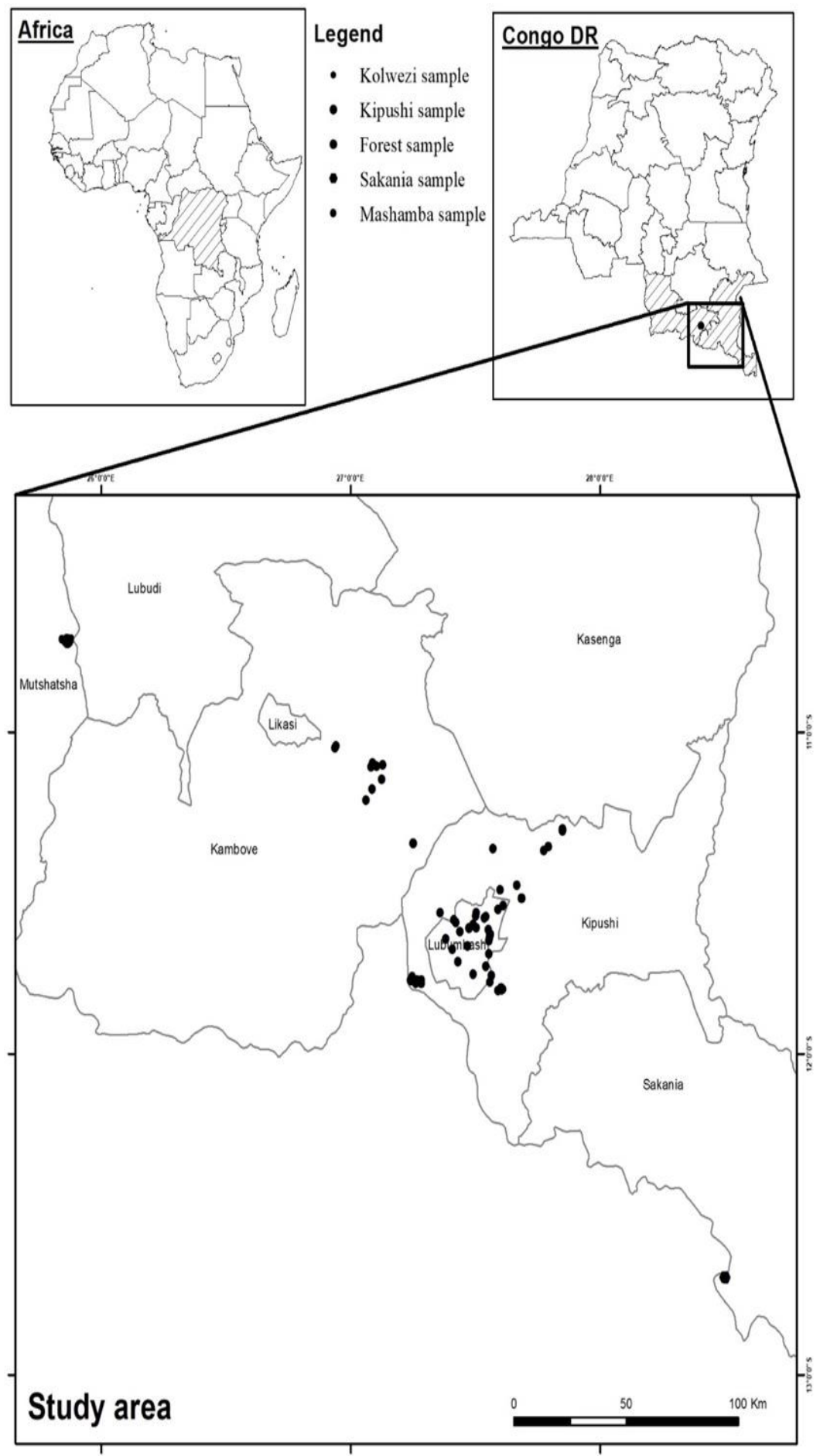

Fig. 1: Sampling areas in the KCA with 3 land uses (cropland, forest and mining area) 
To understand relationships between the $\mathrm{pH}$ and studied trace elements, we transformed our data using best Normalize package in $\mathrm{R}$ to meet the normal distribution requirement of data before calculation of Pearson correlation coefficient (Webster and Lark, 2019).

\section{Results}

\section{Element Contents and pH Across Land uses}

The Principal Component Analysis (ACP) explained over $55 \%$ of variability within the dataset (Fig. 2). The largest variability in metal contents was observed in croplands. The PCA results in two groups of metals positively correlated with each other. The first group consisted of $\mathrm{Cd}, \mathrm{Ti}, \mathrm{Fe}$ and $\mathrm{Zn}$, while the second group consisted of $\mathrm{Ni}, \mathrm{Co}, \mathrm{Cu}, \mathrm{Mn}$ and $\mathrm{Cr}$. The $\mathrm{pH}$ was genitively correlated with $\mathrm{Pb}$ along the dimension 1. Al was strongly associated with samples from forests and mining areas.

The $\mathrm{pH}$ in cropland varied between 3.9 and 7.3 (Table 1). The mean $\mathrm{pH}$ in investigated cropland was 5.3 and 5.4 for arithmetic and geometric mean respectively. The minimum $\mathrm{Al}$ and $\mathrm{Fe}$ concentrations were 16.6 and $10.7 \mathrm{mg}$. $\mathrm{kg}^{-1}$ respectively, whereas their respective maximum concentrations were 282.9 and $215.7 \mathrm{mg} . \mathrm{kg}^{-1}$. Al, Fe and
Mn were the most abundant elements in studied cropland soils, with respectively $63.4,42.2$ and $57.6 \mathrm{mg}$. $\mathrm{kg}^{-1}$ as average concentration in soil. The mean $\mathrm{Cu}$ and $\mathrm{Co}$ concentrations were 5.4 and $1.0 \mathrm{mg} \cdot \mathrm{kg}^{-1}$, respectively. The following elements were found in trace concentrations (maximum concentration $<5 \mathrm{mg} \cdot \mathrm{kg}^{-1}$ ), Cd, $\mathrm{Cr}, \mathrm{Pb}, \mathrm{Zn}$ and $\mathrm{Ni}$.

In forests, $\mathrm{pH}$ varied between 4.0 and 5.2 with an average of 4.3 (Table 2). The most abundant elements were $\mathrm{Al}, \mathrm{Fe}$ and $\mathrm{Mn}$, with respectively 222.2, 162.6 and $163.0 \mathrm{mg} . \mathrm{kg}^{-1}$ on average. Mean $\mathrm{Cu}$ concentration was higher $\left(14.6 \mathrm{mg} \cdot \mathrm{kg}^{-1}\right)$ than that of Co $\left(2.7 \mathrm{mg} \cdot \mathrm{kg}^{-1}\right)$. Up to $31.4 \mathrm{mg}$. $\mathrm{kg}^{-1} \mathrm{Cu}$ and $4.5 \mathrm{mg} . \mathrm{kg}^{-1} \mathrm{Co}$ were found. The maximum concentrations in $\mathrm{Cd}, \mathrm{Cr}, \mathrm{Ni}, \mathrm{Pb}, \mathrm{Zn}$ and Ti were lower than $10 \mathrm{mg} \cdot \mathrm{kg}^{-1}$. In contrast, croplands presented $\mathrm{Cr}$ soil contents up to a maximum of $44.9 \mathrm{mg} \cdot \mathrm{kg}^{-1}$ with an average of $6.1 \mathrm{mg} \cdot \mathrm{kg}^{-1}$.

In the mining area, $\mathrm{pH}$ varied between 4.2 and 6.8 with an average of $5.8 . \mathrm{Cu}$ was the most abundant metal, with a maximum of $1828.0 \mathrm{mg} . \mathrm{kg}-1$ and an average of 424 mg.kg-1 (Table 3). Following Cu, Zn concentrations were found up to a maximum of $1410.0 \mathrm{mg} . \mathrm{kg}^{-1}$ and an average of $408.2 \mathrm{mg} \cdot \mathrm{kg}^{-1}$. Mean $\mathrm{Al}$, Fe and $\mathrm{Mn}$ concentrations were respectively 60.5, 105.3, $32.4 \mathrm{mg} . \mathrm{kg}$ ${ }^{1}$. $\mathrm{Cr}, \mathrm{Ni}$ and $\mathrm{Ti}$ were found in lower concentrations, with a maximum of $1.0,1.7,1.2 \mathrm{mg} \cdot \mathrm{kg}^{-1}$ respectively.

Table 1: Descriptive statistics of element contents $\left(\mathrm{mg}^{\mathrm{kg}} \mathrm{kg}^{-1}\right)$ and $\mathrm{pH}$ in croplands $(\mathrm{n}=450)$.

\begin{tabular}{|c|c|c|c|c|c|c|c|c|c|c|c|c|}
\hline & $\mathrm{Al}$ & $\mathrm{Cd}$ & $\mathrm{Co}$ & $\mathrm{Cr}$ & $\mathrm{Cu}$ & $\mathrm{Fe}$ & Mn & $\mathrm{Ni}$ & $\mathrm{Pb}$ & $\mathrm{Zn}$ & $\mathrm{Ti}$ & $\mathrm{pH}$ \\
\hline Minimum & 16.6 & 0.0 & 0.1 & 0.0 & 1.1 & 10.7 & 2.8 & 0.1 & 0.0 & 0.0 & 0.1 & 3.9 \\
\hline Maximum & 282.9 & 0.4 & 16.0 & 0.4 & 160.7 & 215.7 & 323.0 & 2.6 & 2.2 & 3.9 & 100.5 & 7.3 \\
\hline Median & 51.5 & 0.1 & 0.5 & 0.1 & 3.4 & 30.4 & 46.7 & 0.2 & 0.7 & 1.4 & 0.9 & 5.2 \\
\hline $\mathrm{AM}$ & 63.4 & 0.1 & 1.0 & 0.1 & 5.4 & 42.2 & 57.6 & 0.3 & 0.7 & 1.3 & 16.4 & 5.4 \\
\hline ASD & 37.4 & 0.0 & 1.8 & 0.0 & 12.0 & 35.9 & 42.9 & 0.3 & 0.4 & 0.7 & 20.0 & 0.8 \\
\hline GM & 54.6 & 0.0 & 0.5 & 0.1 & 3.7 & 33.0 & 44.8 & 0.2 & 0.6 & 1.0 & 2.4 & 5.3 \\
\hline GSD & 1.7 & 1.4 & 2.5 & 1.6 & 2.2 & 2.7 & 3.6 & 2.0 & 2.0 & 4.5 & 12.7 & 1.2 \\
\hline $\mathrm{GSD}^{2}$ & 3.0 & 1.9 & 6.5 & 2.7 & 4.7 & 7.1 & 12.9 & 3.9 & 4.1 & 20.0 & 162.4 & 1.4 \\
\hline GM/GSD 2 & 18.4 & 0.0 & 0.1 & 0.0 & 0.8 & 4.7 & 3.5 & 0.1 & 0.1 & 0.1 & 0.0 & 3.8 \\
\hline $\mathrm{GM}^{*} \mathrm{GSD}^{2}$ & 162.0 & 0.1 & 3.5 & 0.2 & 17.7 & 233.8 & 575.6 & 0.9 & 2.4 & 20.3 & 392.6 & 7.5 \\
\hline
\end{tabular}

Table 2: Descriptive statistics of element contents $\left(\mathrm{mg}^{\mathrm{kg}} \mathrm{kg}^{-1}\right)$ and $\mathrm{pH}$ in forests $(\mathrm{n}=16)$

\begin{tabular}{|c|c|c|c|c|c|c|c|c|c|c|c|c|}
\hline & $\mathrm{Al}$ & $\mathrm{Cd}$ & Co & $\mathrm{Cr}$ & $\mathrm{Cu}$ & $\mathrm{Fe}$ & $\mathrm{Mn}$ & $\mathrm{Ni}$ & $\mathrm{Pb}$ & $\mathrm{Zn}$ & $\mathrm{Ti}$ & $\mathrm{pH}$ \\
\hline Minimum & 38.9 & 0.0 & 0.1 & 0.4 & 3.2 & 74.3 & 4.3 & 0.2 & 0.3 & 2.0 & 0.2 & 4.0 \\
\hline Maximum & 401.9 & 0.4 & 4.5 & 44.9 & 31.4 & 253.6 & 370.0 & 7.6 & 7.5 & 6.8 & 0.7 & 5.2 \\
\hline Median & 302.5 & 0.1 & 2.7 & 2.1 & 10.5 & 158.6 & 115.5 & 0.5 & 1.3 & 3.8 & 0.4 & 4.2 \\
\hline $\mathrm{AM}$ & 222.2 & 0.1 & 2.7 & 6.1 & 14.6 & 162.6 & 163.0 & 2.8 & 2.8 & 3.9 & 0.4 & 4.3 \\
\hline ASD & 160.9 & 0.1 & 1.6 & 11.3 & 8.4 & 44.8 & 134.1 & 3.0 & 2.4 & 1.2 & 0.1 & 0.4 \\
\hline GM & 148.0 & 0.1 & 1.9 & 2.2 & 12.3 & 156.4 & 86.9 & 1.1 & 1.9 & 3.7 & 0.4 & 4.3 \\
\hline GSD & 2.8 & 2.3 & 3.1 & 3.9 & 1.9 & 1.3 & 4.2 & 4.7 & 2.7 & 1.4 & 1.4 & 1.1 \\
\hline $\mathrm{GSD}^{2}$ & 7.9 & 5.1 & 9.6 & 15.3 & 3.5 & 1.8 & 17.7 & 21.7 & 7.3 & 1.9 & 2.1 & 1.2 \\
\hline GM/GSD 2 & 18.8 & 0.0 & 0.2 & 0.1 & 3.6 & 86.4 & 4.9 & 0.1 & 0.3 & 2.0 & 0.2 & 3.6 \\
\hline $\mathrm{GM}^{*} \mathrm{GSD}^{2}$ & 1167.1 & 0.5 & 18.1 & 33.7 & 42.7 & 283.3 & 1538.9 & 24.2 & 13.7 & 7.0 & 0.8 & 5.1 \\
\hline
\end{tabular}


Martin T. Mpinda et al. / American Journal of Environmental Sciences 2021, 17 (6): 125.135 DOI: 10.3844/ajessp.2021.125.135

Table 3: Descriptive statistics of element contents $\left(\mathrm{mg}^{\mathrm{kg}} \mathrm{kg}^{-1}\right)$ and $\mathrm{pH}$ in the mining areas $(\mathrm{n}=24)$

\begin{tabular}{|c|c|c|c|c|c|c|c|c|c|c|c|c|}
\hline & $\mathrm{Al}$ & $\mathrm{Cd}$ & Co & $\mathrm{Cr}$ & $\mathrm{Cu}$ & $\mathrm{Fe}$ & $\mathrm{Mn}$ & $\mathrm{Ni}$ & $\mathrm{Pb}$ & $\mathrm{Zn}$ & $\mathrm{Ti}$ & $\mathrm{pH}$ \\
\hline Minimum & 7.3 & 0.0 & 0.6 & 0.0 & 8.6 & 15.8 & 10.3 & 0.2 & 0.8 & 6.1 & 0.1 & 4.2 \\
\hline Maximum & 222.8 & 52.2 & 527.2 & 1.0 & 1828.0 & 700.9 & 92.5 & 1.7 & 182.2 & 1410.0 & 1.2 & 6.8 \\
\hline Median & 39.8 & 1.0 & 3.8 & 0.1 & 154.1 & 38.5 & 24.2 & 0.3 & 3.8 & 56.6 & 0.3 & 6.1 \\
\hline $\mathrm{AM}$ & 60.5 & 9.0 & 41.2 & 0.1 & 424.0 & 105.3 & 32.4 & 0.6 & 37.7 & 408.2 & 0.4 & 5.8 \\
\hline ASD & 52.8 & 14.3 & 111.9 & 0.2 & 549.4 & 158.2 & 23.3 & 0.5 & 55.7 & 519.4 & 0.3 & 0.7 \\
\hline GM & 42.8 & 1.3 & 7.0 & 0.1 & 115.5 & 53.3 & 26.1 & 0.5 & 8.2 & 93.1 & 0.3 & 5.8 \\
\hline GSD & 2.4 & 11.4 & 5.5 & 1.9 & 6.9 & 3.0 & 1.9 & 2.0 & 6.9 & 7.8 & 1.9 & 1.1 \\
\hline $\mathrm{GSD}^{2}$ & 5.8 & 130.6 & 30.2 & 3.6 & 47.5 & 9.0 & 3.7 & 4.1 & 47.8 & 60.5 & 3.7 & 1.3 \\
\hline GM/GSD 2 & 7.4 & 0.0 & 0.2 & 0.0 & 2.4 & 5.9 & 7.1 & 0.1 & 0.2 & 1.5 & 0.1 & 4.5 \\
\hline $\mathrm{GM}^{*} \mathrm{GSD}^{2}$ & 247.2 & 164.8 & 211.3 & 0.4 & 5485.5 & 481.7 & 95.9 & 1.9 & 390.8 & 5629.3 & 1.3 & 7.4 \\
\hline
\end{tabular}

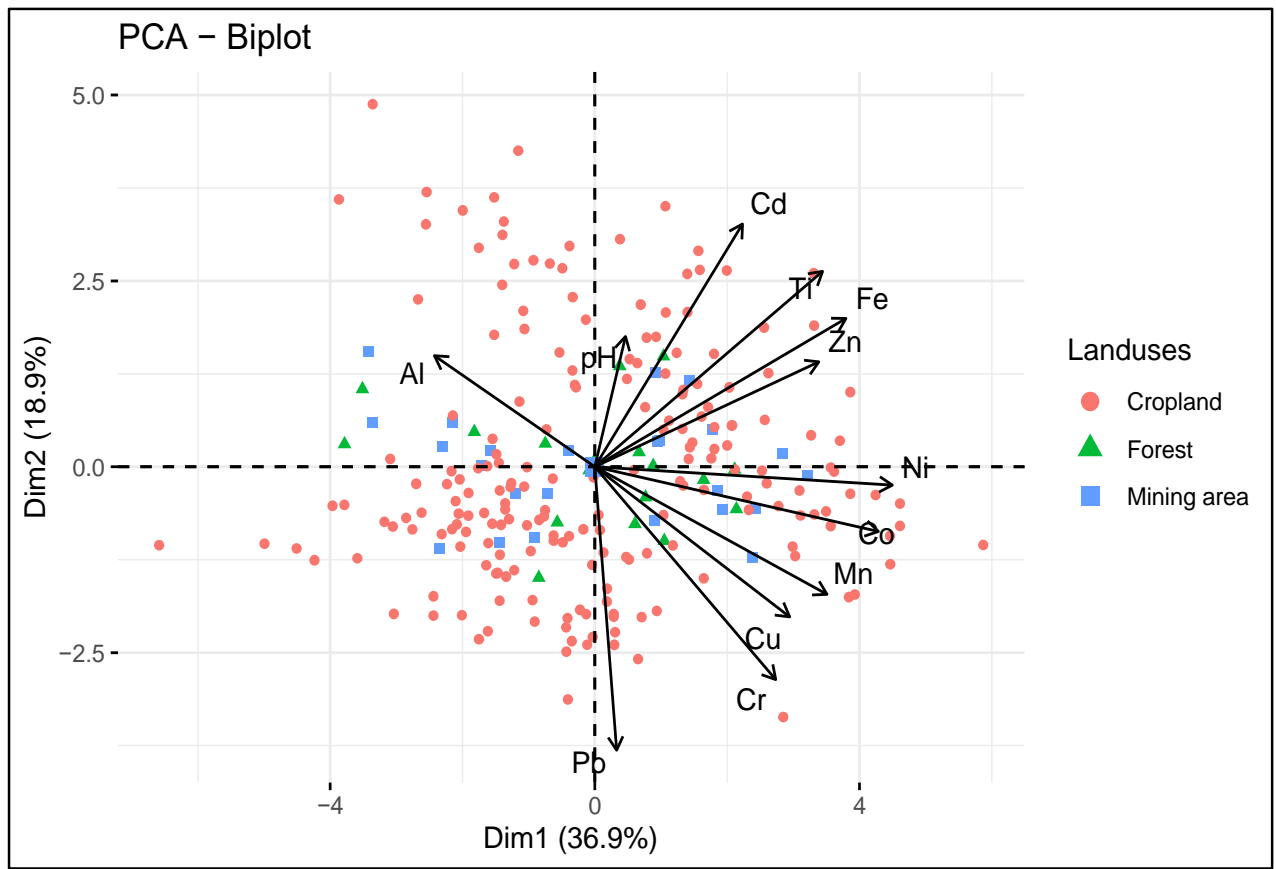

Fig. 2: Principal component analysis showing variability of studied elements across 3 land uses (cropland, forest and mining area)
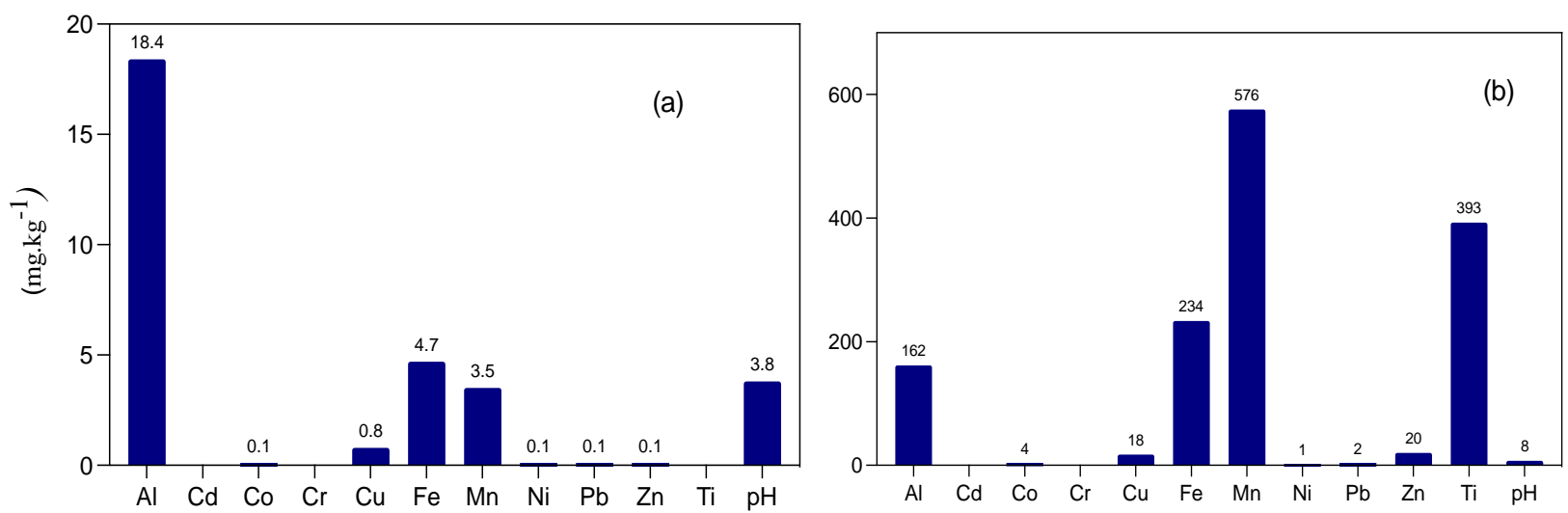

Fig. 3: Minimum (a) and maximum (b) baseline concentrations of elements and $\mathrm{pH}$ in croplands 


\section{Baseline Concentrations of Elements and pH Across Different Land uses}

The lower and upper limits of $\mathrm{pH}$ in croplands were 3.8-8.0 (Fig. 3). The minimum expectable Al content (baseline) in cropland was $18.4 \mathrm{mg} \cdot \mathrm{kg}^{-1}$ while the maximum was $162 \mathrm{mg}$. $\mathrm{kg}^{-1}$. Minimum and maximum baseline Fe concentrations was 4.7-234.0 mg.kg-1. Baseline Mn concentrations varied between 3.5-576.0 mg. kg-1. The minimum baseline $\mathrm{Cu}$ and $\mathrm{Co}$ concentrations were 0.1 and $0.8 \mathrm{mg} \cdot \mathrm{kg}^{-1}$ while the maximum was 4.0 and $18.0 \mathrm{mg} \cdot \mathrm{kg}^{-1}$.

In the forests, minimum-maximum baseline $\mathrm{pH}$ was 3.6-5.0 (Fig. 4). Minimum baseline $\mathrm{Al}$ and $\mathrm{Fe}$ concentrations were respectively 18.8 and $86.4 \mathrm{mg} \cdot \mathrm{kg}^{-1}$ while the maximum baseline concentrations were 1167 and $283 \mathrm{mg} . \mathrm{kg}^{-1}$. Minimum and maximum baseline $\mathrm{Mn}$ concentrations varied between 4.9 and 1539 mg. $\mathrm{kg}^{-1}$. Obtained baseline $\mathrm{Cu}$ concentrations was 3.6-43.0 mg. $\mathrm{kg}^{-1}$ while that of Co was $0.2-18.0 \mathrm{mg} . \mathrm{kg}^{-1}$.

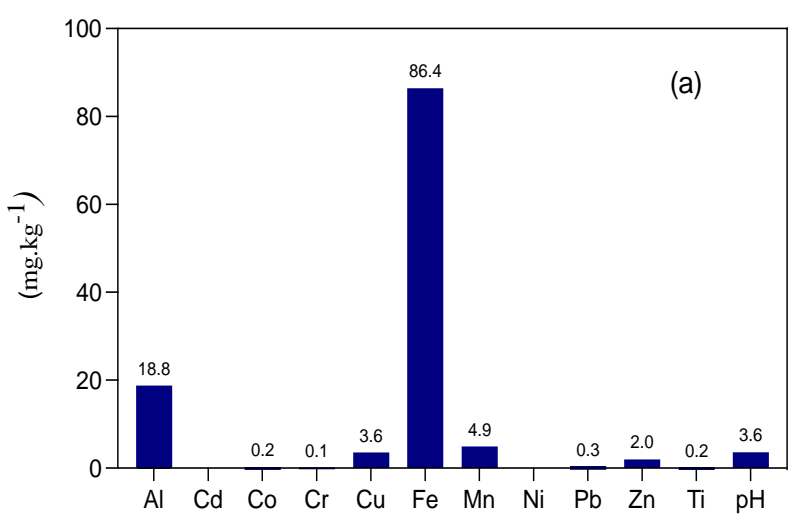

Baseline $\mathrm{pH}$ observed in the mining areas was 4.5-7.0 (Fig. 5). Minimum baseline $\mathrm{Al}$ and $\mathrm{Fe}$ concentrations were 7.4 and 5.9 mg.kg-1 while the maximum baseline concentrations were 247.0 and $482.0 \quad \mathrm{mg} \cdot \mathrm{kg}^{-1}$ respectively. Baseline $\mathrm{Mn}$ and $\mathrm{Zn}$ concentrations were 7.1-86.0 mg. $\mathrm{kg}^{-1}$ and $1.5-5.629 \mathrm{mg} . \mathrm{kg}^{-1}$ respectively. Baseline $\mathrm{Cu}$ concentration was 2.4-5485 mg.kg-1 while that of Co was $0.2-211 \mathrm{mg} \cdot \mathrm{kg}^{-1}$.

\section{Correlations between $\mathrm{pH}$ and Studied Elements}

In croplands, $\mathrm{pH}$ was negatively correlated with $\mathrm{Co}$, $\mathrm{Fe}$ and $\mathrm{Zn}$ but positively correlated with $\mathrm{Cu}, \mathrm{Al}$ and $\mathrm{Zn}$. However, none of these correlations was statistically significant (Fig. 6 a, d, g). In mining areas, $\mathrm{pH}$ was negatively correlated with Al while positively significantly correlated with $\mathrm{Fe}$ and $\mathrm{Zn}$. A positive but non-statistically significant correlations of $\mathrm{pH}$ with $\mathrm{Cu}$ and Co were observed. In the forests, $\mathrm{pH}$ was negatively and significantly correlated with $\mathrm{Mn}$ and $\mathrm{Co}$, but positively and significantly correlated with Al.

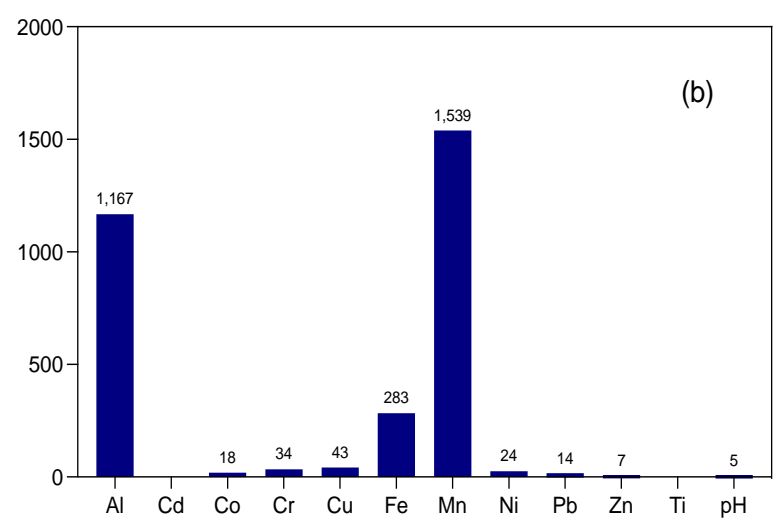

Fig. 4: Minimum (a) and maximum (b) baseline concentrations of elements and $\mathrm{pH}$ in forests
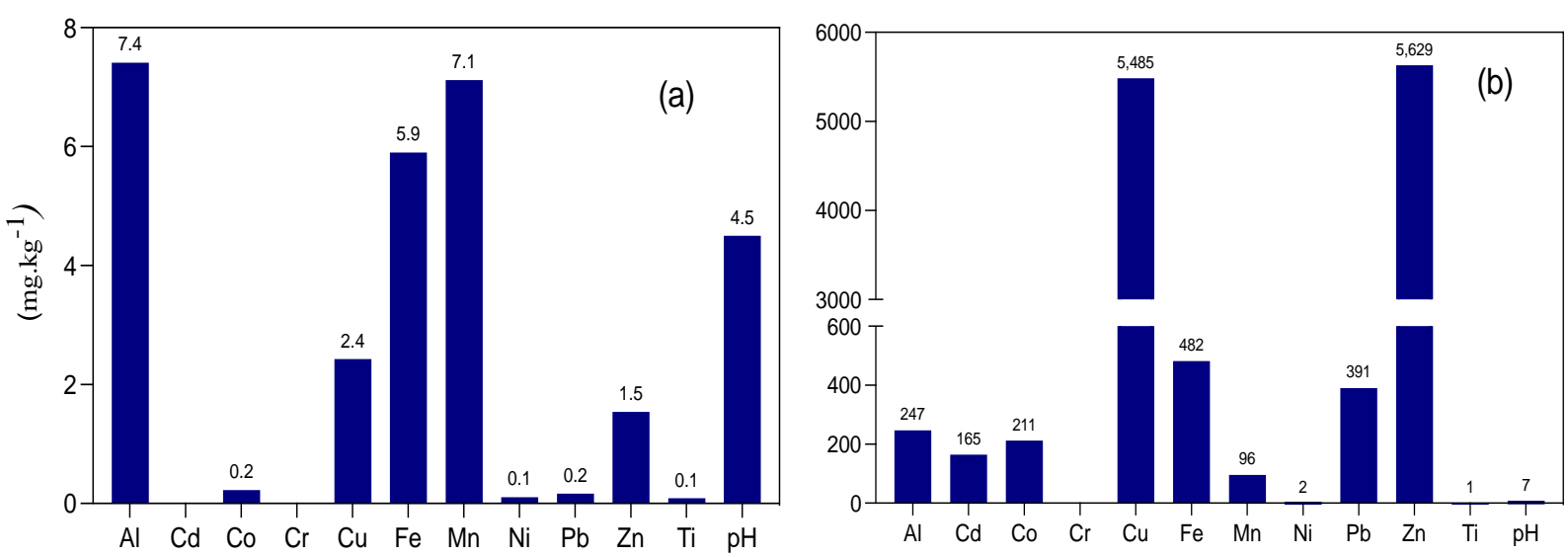

Fig. 5: Minimum (a) and maximum (b) baseline concentrations of elements and $\mathrm{pH}$ in mining areas 

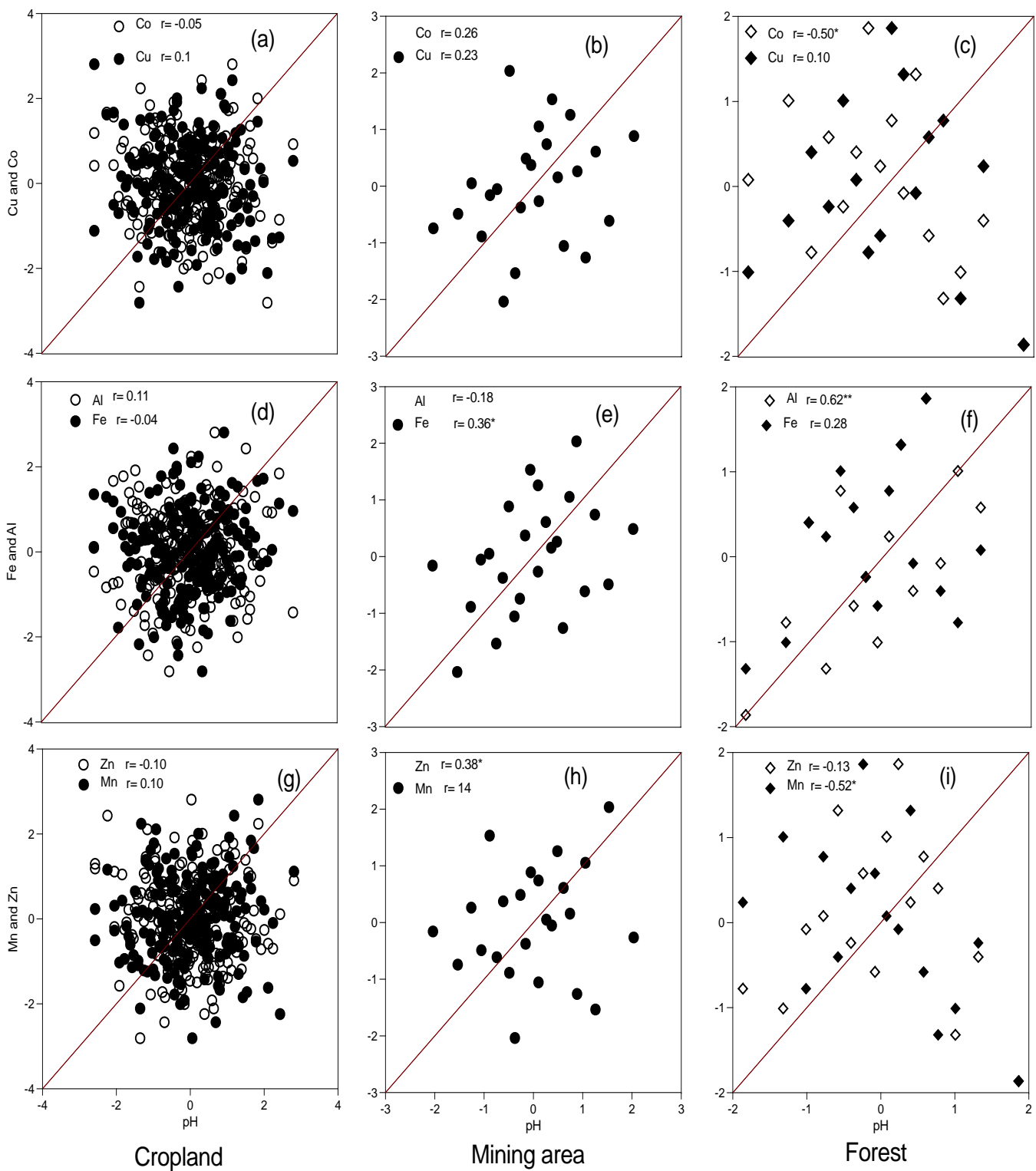

Fig. 6: Correlations of $\mathrm{pH}$ with studied elements across land uses. Number of observations = 450 (cropland), 24 (mining sites) and 16 (forest)

\section{Discussion}

Soils across investigated land uses were acidic with a mean $\mathrm{pH}$ lower than 6 , which is in accordance with previous studies in the regions (Kasongo et al., 2013). However, the baseline $\mathrm{pH}$ in studied land uses varied from acidic to alkaline soils, with 3.8-8.0 for croplands, 3.6-5.0 for forests and 4.5-7.0 for mining areas (Fig. 4-5). These results suggest that although studied soils are globally characterized as acidic, the $\mathrm{pH}$ at some locations can be neutral or alkaline as observed for mining areas and croplands respectively. Surprisingly, soils in the mining areas and croplands showed higher $\mathrm{pH}$ compared to forests, which would come from the difference between soil units. The possibility that the use of lime in mining areas during waste treatment and cropland could be raised to explain the elevated $\mathrm{pH}$. Additionally, we cannot rule out the possibility that organic matter decomposition and the inherent organic acidic production in forests soils may lower the $\mathrm{pH}$. Compared to other land uses, croplands showed the largest range from lower and upper limit of reported $\mathrm{pH}$ baseline $(3.8-8.0)$. This is an indication that $\mathrm{pH}$ in croplands can be largely variable as a result of differences in soil management and cropping systems. Though, the variation may simply be due to differences in soil units. 
More interestingly, results delineated a considerable variability of element concentrations across different land use allocations (Table 1-3). The most abundant elements in croplands were $\mathrm{Al}, \mathrm{Fe}$ and $\mathrm{Mn}$ with 63.4, 42.2 and $57.6 \mathrm{mg} . \mathrm{kg}^{-1}$ on average respectively. One of the typical characteristics of tropical soils is their marked alteration with rather lower $\mathrm{pH}$ values (Upadhyay and Raghubanshi, 2020). Coincidentally, Al, Fe and Mn were also the most abundant elements in forests, with values averaging 222.2, 162.6 and $163.0 \mathrm{mg} . \mathrm{kg}^{-1}$ respectively. In mining areas on contrary, soils were dominated by $\mathrm{Cu}$ (424 mg.kg-1) and $\mathrm{Zn}\left(408.2 \mathrm{mg} . \mathrm{kg}^{-1}\right.$ ). This accumulation could be linked to the complexation of these cations with organic acids in forest soils.

We suppose that these element concentrations do not reflect their natural abundance since ongoing human activities related to agriculture and mining are likely to alter natural distribution and concentration patterns of metals in comparison to their concentrations in the underlying parent materials. However, baseline element concentrations presented here, reflect their common occurrence in the study area and can thus be used as reference values for soil quality. The high concentrations of trace elements in the soils of different sites in the Katangese Copperbelt area have already been reported by several authors (Malaisse, 1999; Leteinturier et al., 1999; Mpundu et al., 2013). The upper limits of $\mathrm{Cu}$ and $\mathrm{Co}$ concentrations in forest soils were higher compared to cropland soils. This is an indication that in the Katangese Copperbelt area, even non-disturbed areas can contain significantly higher $\mathrm{Cu}$ and $\mathrm{Co}$ without a direct human activity. Nevertheless, $\mathrm{Cu}, \mathrm{Co}, \mathrm{Pb}$ and $\mathrm{Zn}$ contents found in forest and cropland soils were significantly lower than those reported by Ngoy et al. (2018) as upper limits of their natural geochemical background in the Lubumbashi region (400, 50, 120 and $200 \mathrm{mg} . \mathrm{kg}-1$ for total $\mathrm{Cu}, \mathrm{Co}, \mathrm{Pb}$ and $\mathrm{Zn}$ respectively). Moreover, the ranges of trace element concentrations reported in this study are significantly wider than those reported in several studies carried out in other regions (Kaminski and Landsberger, 2000; Tarvainen and Kallio, 2002; Krishna and Govil, 2004; Massas et al., 2013; Paulette et al., 2015). These discrepancies could be related to differences in sample size, sampling strategies sampling areas and analytical methods. Indeed, contrast to Ngoy et al. (2018) who used data reported in studies that focused in potentially polluted areas with sample size lower than 50, in this study, 490 samples were used, thus covering a larger set of soils with potentially varied properties.

In the Katanga Copperbelt area in general and the Lubumbashi area in particular, mining activities have possibly modified natural metal contents in soils, making comparisons with international or regional reference values inappropriate for environmental studies. It was reported that in all cases in Lubumbashi soils, total $\mathrm{Cu}, \mathrm{Co}, \mathrm{Zn}$ and $\mathrm{Pb}$ concentrations are higher in surface layers than the deeper ones (Ngoy et al., 2018). It is therefore possible that the element concentrations observed across land uses in this study are a result of combination of the soil geochemical background that is naturally rich in these elements (Mpundu, 2010; Kaya et al., 2015) and the intensification of anthropogenic activities (Gustin et al., 2008).

We observed that $\mathrm{pH}$ was negatively correlated with $\mathrm{Co}, \mathrm{Fe}$ and $\mathrm{Zn}$ but positively correlated with $\mathrm{Cu}, \mathrm{Al}$ and $\mathrm{Zn}$ in croplands. However, none of these correlations was statistically significant (Fig. 6 a, d, g). In mining areas, $\mathrm{pH}$ was negatively correlated with $\mathrm{Al}$, but positively correlated with $\mathrm{Fe}$ and $\mathrm{Zn}$. In the forests, $\mathrm{pH}$ was negatively and significantly correlated with $\mathrm{Mn}$ and Co, but positively and significantly correlated with Al. These relationships suggest a lack of a direct and strong $\mathrm{pH}$-dependence of measured elements. As $\mathrm{pH}-\mathrm{KCl}$ measured in this study reflects total soil acidity rather than the actual acidity, the concentrations of metals would likely be strongly related to $\mathrm{pH}-\mathrm{H}_{2} \mathrm{O}$. Nevertheless, our results showed contrasting and poor relationship of $\mathrm{pH}$ with metals depending on the land use. The lack of strong correlation between metals and pH was also observed by Tume et al. (2006) who argued that their observation was possibly due to the very wide range of $\mathrm{pH}$, having little influence on elemental behaviour.

\section{Conclusion}

This study has provided crucial information regarding lower and upper limits of trace element concentrations expected in surface soils of the Katangese Copperbelt Area (KCA). The identified baseline data did not reflect the natural geochemical abundance of elements, suggesting a predominant influence of ongoing anthropogenic activities in the region (i.e., Agriculture and Mining) over natural processes. Overall, mining activities were found to induce the greatest influence on the baseline concentrations of elements, particularly for $\mathrm{Cu}$ and $\mathrm{Zn}$. Comparatively, Agriculture generated mild effects on the natural background concentrations of metals, as a similar trend of Al and Mn distribution was recorded in croplands and forests. Results also provided indication of possible variability in natural background concentrations of metals in the region, with forests presenting significantly higher $\mathrm{Cu}$ and $\mathrm{Co}$ contents than croplands.

\section{Data Availability Statement}

Data used in this study can be obtained from the corresponding author upon reasonable request. 


\section{Author's Contributions}

Martin T. Mpinda: Conceptualization, Design, data acquisition methodology, software, formal analysis, investigation, resources, data curation, writing original draft preparation.

Theodore M. Mwamba: Methodology, analysis and interpretation of data and drafting the article.

Emery L.M. Kasongo: Data validation, supervision.

Arthur T. Kaniki: Supervision, writing review and editing.

Basile B. Mujinya: Conceptualization, methodology, data validation, resources, supervision.

Trésor Kismba Ngobila: Methodology, software, investigation and data curation.

\section{Ethics}

This article is original and contains unpublished material. We confirm that all authors have read and approved the manuscript and there are no conflicts of interest.

\section{References}

Albright E. I. (1998). Background concentrations of trace elements in soils and rocks of the georgia piedmont, The University of Georgia.

https://getd.libs.uga.edu/pdfs/albright_evalyn_i_200 405_ms.pdf

Baize, D., \& Sterckeman, T., (2001), On the necessity of knowledge of the natural pedo-geochemical background content in the evaluation of the contamination of soils by trace elements. Science Total Environment, 264, 127-139. doi.org/10.1016/S0048-9697(00)00615-X

Ballesta, R. J., Paz, C. B., Juan, A., Rubí, M., \& Giménez, R.G. (2010), Pedo-geochemical baseline content levels and soil quality reference values of trace elements in soils from the Mediterranean (Castilla La Mancha, Spain). Central European Journal of Geosciences, 2, 441-454, doi.org/10.2478/v10085-010-0028-1

Banza, C. L. N., Nawrot, T. S., Haufroid, V., Decrée, S., De Putter, T., Smolders, E., ... \& Nemery, B. (2009). High human exposure to cobalt and other metals in Katanga, a mining area of the Democratic Republic of Congo. Environmental research, 109(6), 745-752. doi.org/10.1016/j.envres.2009.04.012

Batumike, M. J., Cailteux, J. L. H., \& Kampunzu, A. B. (2007). Lithostratigraphy, basin development, base metal deposits and regional correlations of the Neoproterozoic Nguba and Kundelungu rock successions, central African Copperbelt. Gondwana Research, 11(3), 432-447. doi.org/10.1016/j.gr.2006.04.012
Cailteux, J. L. H., Kampunzu, A. B., Lerouge, C., Kaputo, A. K., \& Milesi, J. P. (2005). Genesis of sediment-hosted stratiform copper-cobalt deposits, central African Copperbelt. Journal of African Earth Sciences, 42(1-5), 134-158. doi.org/10.1016/j.jafrearsci.2005.08.001

Dudka, S., \& Markert, B. (1992). Baseline concentrations of $\mathrm{As}, \mathrm{Ba}, \mathrm{Be}, \mathrm{Li}, \mathrm{Nb}, \mathrm{Sr}$ and $\mathrm{V}$ in surface soils of Poland. Science of the total environment, 122(3), 279-290. doi.org/10.1016/0048-9697 (92)90046-U

Gustin, M. S., Lindberg, S. E., \& Weisberg, P. J. (2008). An update on the natural sources and sinks of atmospheric mercury. Applied Geochemistry, 23(3), 482-493. doi.org/10.1016/j.apgeochem.2007.12.010

Herselman, J. E. (2007). The concentration of selected trace metals in South African soils (Doctoral dissertation, Stellenbosch: University of Stellenbosch). http://scholar.sun.ac.za/handle/10019.1/1390

Kaminski, M. D., \& Landsberger, S. (2000). Heavy metals in urban soils of East St. Louis, IL, part I: Total concentration of heavy metals in soils. Journal of the Air \& Waste Management Association, 50(9), 1667-1679. doi.org/10.1080/10473289.2000.10464195.

Kampunzu, A. B., Cailteux, J. L. H., Kamona, A. F., Intiomale, M. M., \& Melcher, F. (2009). Sedimenthosted $\mathrm{Zn}-\mathrm{Pb}-\mathrm{Cu}$ deposits in the Central African Copperbelt. Ore Geology Reviews, 35(3-4), 263-297. doi.org/10.1016/j.oregeorev.2009.02.003

Kampunzu, A. B., Tembo, F., Matheis, G., Kapenda, D., \& Huntsman-Mapila, P. (2000). Geochemistry and tectonic setting of mafic igneous units in the Neoproterozoic Katangan Basin, Central Africa: Implications for Rodinia break-up. Gondwana Research, 3(2), 125-153. doi.org/10.1016/S1342-937X(05)70093-9

Kasongo, L. M. E., Mwamba, M. T., Tshipoya, M. P., Mukalay, M. J., Useni, S. Y., Mazinga, K. M., \& Nyembo, K. L. (2013). Réponse de la culture de soja (Glycine max L.(Merril) à l'apport des biomasses vertes de Tithonia diversifolia (Hemsley) A. Gray comme fumure organique sur un Ferralsol à Lubumbashi, RD Congo. Journal of Applied Biosciences, 63, 4727-4735. doi.org/10.4314/jab.v63i1.87247

Katemo, M. B., Clinet, G. andré, L., Chocha, M. A. Marquet, J-P., Micha, J. C. (2010). Les éléments traces $(\mathrm{Cu}, \mathrm{Co}, \mathrm{Zn}, \mathrm{Pb}, \mathrm{Cd}, \mathrm{U}, \mathrm{V}$ et As) dans le bassin de la Lufira supérieure (Katanga/RD Congo). Tropicultura, 28, 246-252.

http://www.tropicultura.org/index/author/katemomanda-b.html

Kaya Muyumba, D., Liénard, A., Mahy, G., Ngongo Luhembwe, M., \& Colinet, G. (2015). Caractérisation des systèmes sols-plantes dans les collines de l'arc cuprifère du Katanga (synthèse bibliographique). Biotechnologie, Agronomie, Société et Environnement, 19(2), 204-214. https://orbi.uliege.be/handle/2268/179166 
Krishna, A. K., \& Govil, P. K. (2004). Heavy metal contamination of soil around Pali industrial area Rajasthan, India. Environmental Geology, 47(1), 38-44. doi.org/10.1007/s00254-004-1124-y

Leblanc, M., \& Malaisse, F. (1978). Lubumbashi, un écosystème urbain tropical. Centre international de sémiologie, Université nationale du Zaïre.

Leteinturier, B., \& Malaisse, F. (1999). De la réhabilitation des sites pollués par l'exploitation minière du cuivre en Afrique centro-australe. Bulletin des séances= Mededelingen der zittingen, 45(4), 535-554.

Leteinturier, B., Baker, A. J., \& Malaisse, F. (1999). Early stages of natural revegetation of metalliferous mine workings in South Central Africa: A preliminary survey. BASE. https://popups.uliege.be/17804507/index.php?id=15734

Lubalega, T., Ngongo, M., Lejoly, J., \& Colinet, G. (2015). Contaminations en éléments traces métalliques des termitières autour de Lubumbashi. Congo Sciences. https://orbi.uliege.be/handle/2268/207893

Malaisse, F. (1973). Contribution à l'étude de l'écosystème forêt claire (Miombo). Ann. Univ. Abidjan Serie E, Ecologie, 6, 227-250.

Malaisse, F. (1999). Se nourrir en forêt claire africaine. Approche écologique et nutritionnelle. Nature Sciences Société, 3(7), 88. doi.org/10.1016/S1240-1307(99)80558-5

Malaisse, F. P. (1974). Phenology of the Zambezian woodland area with emphasis on the miombo ecosystem. In Phenology and seasonality modeling (pp. 269-286). Springer, Berlin, Heidelberg. doi.org/10.1007/978-3-642-51863-8_23

Massas, I., Kalivas, D., Ehaliotis, C., \& Gasparatos, D. (2013). Total and available heavy metal concentrations in soils of the Thriassio plain (Greece) and assessment of soil pollution indexes. Environmental monitoring and assessment, 185(8), 6751-6766. doi.org/10.1007/s10661-013-3062-1

Mpundu, M. M. (2010). Contaminations des sols en éléments traces métalliques à Lubumbashi (Katanga RDC). Évaluation des risques de contamination de la chaine alimentaire et choix des solutions de remediation. Thèse de doctorat, Université de Lubumbashi, $401 \mathrm{p}$.

Mpundu, M. M., Useni, S. Y., Mwamba, M. T., Kateta, M. G., Mwansa, M. E., Ilunga, K., Kamengwa, K. C., Kyungu, K., \& Nyembo, K. L. (2013) Teneurs en éléments traces métalliques dans les sols de différents jardins potagers de la ville minière de Lubumbashi et risques de contamination des cultures potagères. Journal of Applied Biosciences, 65, 4957-4968. doi.org/10.4314/jab.v65i0.89622
Mujinya, B. B., Adam, M., Mees, F., Bogaert, J., Vranken, I., Erens, H., ... \& Van Ranst, E. (2014). Spatial patterns and morphology of termite (Macrotermes falciger) mounds in the Upper Katanga, DR Congo. Catena, 114, 97-106. doi.org/10.1016/j.catena.2013.10.015

Ngoy, S. M., Mukobo, R. P., Kaya, M. D., Mpundu, M. M., Faucon, M. P., Lubalega, K. T. andres, L., John, A., Vandenheede, N., Pourret, O., Ngongo, L. M., COlinet, G., (2018). Fond pédogéochimique et cartographie des pollutions des sols à Lubumbashi. In Bogaert, J., Colinet, G. \& Mahy, G., 2018 (eds.). Anthropisation des paysages katangais. Gembloux, Belgique: Presses Universitaires de Liège Agronomie-Gembloux. https://hal.archivesouvertes.fr/hal-02265975/document

Paulette, L., Man, T., Weindorf, D. C., \& Person, T. (2015). Rapid assessment of soil and contaminant variability via portable x-ray fluorescence spectroscopy: Copşa Mică, Romania. Geoderma, 243, 130-140. doi.org/10.1016/j.geoderma.2014.12.025

Saad, L., Parmentier, I., Colinet, G., Malaisse, F., Faucon, M. P., Meerts, P., \& Mahy, G. (2012). Investigating the vegetation-soil relationships on the copper-cobalt rock outcrops of Katanga (DR Congo), an essential step in a biodiversity conservation plan. Restoration Ecology, 20(3), 405-415.

https://onlinelibrary.wiley.com/doi/abs/10.1111/j.1526100X.2011.00786.xdoi.org/10.1111/j.1526100X.R2011.00786.X.

Tack, F. M. G., Verloo, M. G., Vanmechelen, L., \& Van Ranst, E. (1997). Baseline concentration levels of trace elements as a function of clay and organic carbon contents in soils in Flanders (Belgium). Science of the Total Environment, 201(2), 113-123. doi.org/10.1016/S0048-9697(97)00096-X

Tarvainen, T., \& Kallio, E. (2002). Baselines of certain bioavailable and total heavy metal concentrations in Finland. Applied Geochemistry, 17(8), 975-980. doi.org/10.1016/S0883-2927(02)00003-3

Team, R. C. (2013). R: A language and environment for statistical computing.

http://r.meteo.uni.wroc.pl/web/packages/dplR/vignet tes/intro-dplR.pdf

Temminghoff, E. J. M., Van der Zee, S. E. A. T. M., \& De Haan, F. A. M. (1998). Effects of dissolved organic matter on the mobility of copper in a contaminated sandy soil. European Journal of Soil Science, 49(4), 617-628. doi.org/10.1046/j.1365-2389.1998.4940617.x

Tume, P., Bech, J., Longan, L., Tume, L., Reverter, F., \& Sepulveda, B. (2006). Trace elements in natural surface soils in Sant Climent (Catalonia, Spain). Ecological Engineering, 27(2), 145-152. doi.org/10.1016/j.ecoleng.2006.01.004 
Upadhyay, S., \& Raghubanshi, A. S. (2020). Determinants of soil carbon dynamics in urban ecosystems. In Urban Ecology (pp. 299-314). Elsevier. doi.org/10.1016/B978-0-12-820730-7.00016-1

Van Ranst, E., Verloo, M., Demeyer, A., \& Pauwels, J. M., (1999). Manual for the soil chemistry and fertility laboratory-analytical methods for soils and plants, equipment and management of consumables, Belgium, $243 \mathrm{p}$.

http://hdl.handle.net/1854/LU-113771
Webster, R., \& Lark, R. M. (2019). Analysis of variance in soil research: Examining the assumptions. European Journal of Soil Science, 70(5), 990-1000. doi.org/10.1111/ejss.12804

Zhao, F. J., McGrath, S. P., \& Merrington, G. (2007). Estimates of ambient background concentrations of trace metals in soils for risk assessment. Environmental Pollution, 148(1), 221-229. doi.org/10.1016/j.envpol.2006.10.041 